\title{
1. TEXTURE AND MICROSTRUCTURE OF NEOGENE-QUATERNARY SEDIMENTS, ODP SITES 645 AND 646, BAFFIN BAY AND LABRADOR SEA ${ }^{1}$
}

\author{
Michel Cremer ${ }^{2}$
}

\begin{abstract}
The Neogene quaternary deposits cored at Site 645 in Baffin Bay and at Site 646 in the Labrador Sea are mainly terrigenous sediments. A study of grain-size characteristics and of sedimentary structures from thin-section observations allows a more accurate determination of the sedimentary facies and depositional processes involved. Ice-rafted detritus is distinguished as outsized clasts in fine-grained matrix sediments. These first occur in upper Miocene sediments at Site 645 and in the upper Pliocene ( $2.5 \mathrm{Ma}$ ) at Site 646 . Turbidite sequences are restricted at both sites to detrital carbonate, thin-bedded turbidites in the Pleistocene, when the terrigenous supply from ice rafting became dominant. The presence of these turbidites at Site 646, as opposed to the presence of mafic ice-rafted detritus, is related to spillover sediments from the Northwest Atlantic Mid-Ocean Channel (NAMOC). At Site 646, located on the Eirik Ridge, the sediments are fine-grained, strongly bioturbated, and include rare laminated silt layers related to episodes of pronounced bottom-current influence. These sediments resemble most of the silty contourites of sedimentary drifts. At Site 645, pervasive laminations within bioturbated fine sands and sandy silts reveal an unexpectedly strong bottom-current influence until the early Pliocene; these sandy contourites are related to southward-directed flow, probably of arctic water masses to the Labrador Sea.
\end{abstract}

\section{INTRODUCTION}

The Neogene-Quaternary sediments cored at Site 645 in Baffin Bay and at Site 646 in the Labrador Sea (Fig. 1) include a suite of clastic sediments from inferred hemipelagites, ice-rafted detritus, turbidites, and bottom-current-derived deposits. Detailed facies descriptions of lithologic units, geochemical analyses, and other analyses are reported elsewhere in this volume (Thiebault et al., Cremer et al.). Here, I define the sedimentary textures and structures of the cored facies in more detail than was typically done from visual core descriptions during Leg 105 to try to explain more accurately the nature of depositional-involved mechanisms. This study is based on grain-size analyses of samples taken from the dominant lithologies throughout the cored sections and on the observation of microstructures within oriented samples selected from representative intervals. In the following sections, I briefly outline my methods of sample analysis and then describe the main textural characteristics, their vertical evolution, the sedimentary structures observed, and their significance in terms of sedimentary processes for Sites 645 and 646.

\section{METHODS}

The material for this study consisted of $20-\mathrm{cm}^{3}$ samples (about 90 from Site 645 and 55 from Site 646) that were collected from the dominant lithologies, with an average of one sample per core, to look at the vertical evolution of texture throughout the cored section.

Because the biogenic fraction is usually very low, except for a few intervals from Site 646, and because a notable percentage of detrital carbonate occurs in these sediments, grain sizes were determined on bulk samples. Samples were washed through a $63-\mu \mathrm{m}$ sieve. The grain-size distribution of the $<63-\mu \mathrm{m}$ fraction was determined by using a Sedigraph 5000D particle-size analyzer. For Site 645 , sand-sized particles were dry-sieved through $100,160,250$, and $400 \mu \mathrm{m}$ sieves. For Site 646, the very low sand-sized fraction was observed under a binocular microscope. I computed the modal size, the fifth coarser percentile, the median and the mean diameters, the standard deviation, and the skewness

\footnotetext{
${ }^{1}$ Srivastava, S. P., Arthur, M., Clement, B., et al., 1989. Proc. ODP, Sci. Results, 105: College Station, TX (Ocean Drilling Program).

2 Département de Géologie et Océanographie, Université de Bordeaux I, Laboratoire Associé CNRS 197, Avenue des Facultés, 33405 Talence Cedex, France.
}

using moments to characterize the grain-size distribution of the entire sample (Friedman, 1967; Rivière, 1977).

Microstructures were observed from samples (about 50 from Site 645 and 20 from Site 646) collected during Leg 105 that had been selected as being representative of particular structures and devoid of coring disturbance. These oriented samples consist of quarter-round segments of core about $3 \mathrm{~cm}$ wide and $6 \mathrm{~cm}$ long, which were carefully removed from one side of the split cores. They were sliced to about $1 \mathrm{~cm}$ thick, freezedried, and then impregnated with an epoxy resin. The impregnated slices were thin sectioned as for hard rock. Humidification of already dried samples before freeze-drying made impregnation more successful. The unused sediment was subsampled for grain-size analyses.

\section{SITE 645, BAFFIN BAY}

Site 645 lies on the continental slope off southern Baffin Island in a water depth of about $2020 \mathrm{~m}$ (Fig. 1). A nearly complete lower Miocene to Holocene section $(66 \%$ of the cored intervals) was recovered. These sediments are terrigenous and contain few fossils, which makes precise age assignments difficult. Three main lithologic units were distinguished (Fig. 2). Coarse particles up to cobble size are present in lithologic Units I and II, but are of less importance in lithologic Subunit IIIA. Lithologic Subunits IIIB and IIIC are characterized by muddy silts and muddy sands showing indistinct to distinct laminations and a pervasive bioturbation. Shipboard observations and regional seismic data indicate that deep, contour-following currents were a dominant transport agent during the early-middle Miocene, while ice rafting became prevalent from the late Miocene.

\section{Grain-Size Characteristics}

Grain-size study confirms the general lithologic trend that was defined from shipboard core descriptions. This is indicated particularly by the antithetic evolution (Fig. 3) of the coarse fraction $(>250 \mu \mathrm{m})$ and the fine, sand-sized fraction (250-63 $\mu \mathrm{m})$. The former comprises a range of medium sand- to granule-sized particles. Significant percentages with respect to the fine sand fraction first appear at 600 meters below seafloor (mbsf), where the first inferred ice-rafted dropstone was observed. The coarse-particle fraction increases irregularly uphole and reaches its maximum at the top of the hole. In contrast, the bottom samples contain no coarse sand fraction, but do contain a high percentage of fine sand that decreases upward to 750 


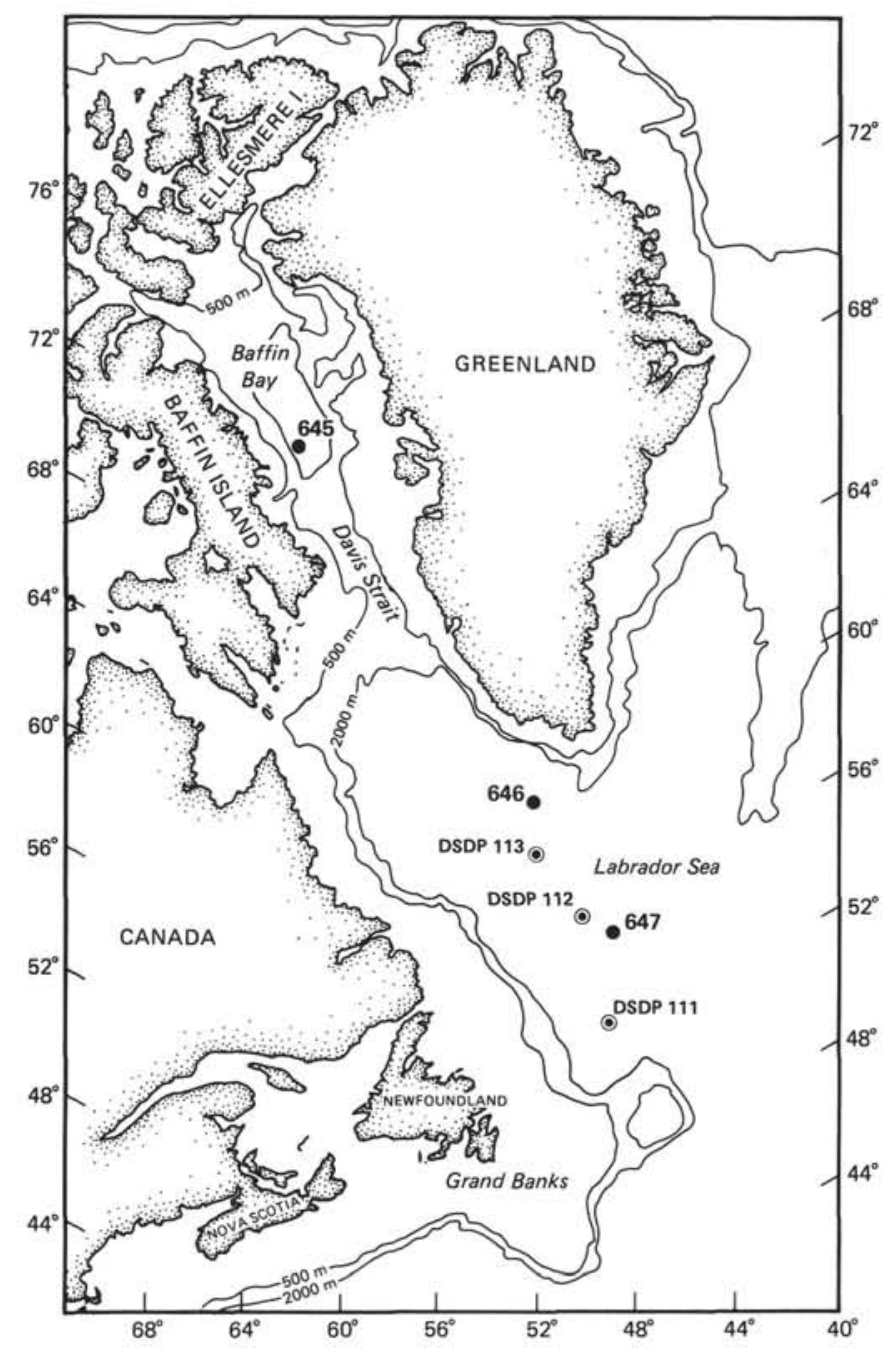

Figure 1. Generalized map of Baffin Bay and Labrador Sea showing locations of sites drilled during Leg 105.

mbsf. Between 750 and 600 mbsf, high percentages are reached again. After a sharp decrease at 600 mbsf, the fine sand fraction remains low, except for short intervals that also are characterized by a lower coarse-particle content. In the same way, the overall clay content decreases only slightly from the bottom of the hole up to $600 \mathrm{mbsf}$, where a sharp increase can be seen. Another abrupt clay enrichment is found at about $460 \mathrm{mbsf}$. Above $460 \mathrm{mbsf}$, the clay content generally varies with the coarse fraction and/or in opposition to the fine sand fraction.

This vertical evolution is also depicted by computed grainsize parameters. The vertical evolution of the modal sizes of samples shows an overall fining-upward sequence, with the two major breaks at 600 and 460 mbsf (Fig. 4A). The standard deviation values reflect the proportion of sand-sized particles (Fig. 4B). According to their high fine sand content, the sediments from the bottom part of the hole are poorly sorted, as are the sediments of the upper part of the hole, which contain a higher coarse fraction. The moderately sorted sediments are either the clayey silts with very low sand content or the sandy silts with low clay content, which occur in the middle part of the section. Skewness values are closely linked to the clay content (Fig. 4C): the lower the clay content, the more the frequency curves are positively asymmetrical with a long fine-sized tail and a sorted coarser fraction. Finally, the diagram of the fifth coarser percentile and median diameter (Passega, 1957) confirms the ab- sence of a relationship between the coarse-particle fraction and the median size in the upper $460 \mathrm{~m}$ (Fig. 5). Conversely, between 460 and 1000 mbsf, the fifth percentile increases with the median diameter to reach a maximum value of about $160 \mu \mathrm{m}$. The presence of diagenetic aggregates in the lowest samples may explain slightly higher values of the fifth percentile.

The above described vertical evolution of grain-size parameters permits the distinction of four main grain-size distributions (Fig. 6).

Type 1 distribution characterizes fine-grained sediments, i.e., clayey silts and silty clays, which contain no coarse particles and no (or very low) fine sand fraction $(<5 \%)$, and a clay content above $30 \%$ and up to $70 \%$. At least $70 \%$ of the grains are smaller than $16 \mu \mathrm{m}$, and the median diameter ranges from 1 to 5 $\mu \mathrm{m}$. These sediments are moderately sorted. The cumulative frequency curves are nearly symmetrical or present a long, coarsegrained tail when higher fine sand contents are present. These curves exhibit hyperbolic to logarithmic shapes (Rivière, 1977).

Type 2 distribution mainly differs from the former by a notable amount of coarse particles (up to $20 \%$ ). This $>250-\mu \mathrm{m}$ fraction is of the the same order of importance as the fine sand fraction. The clay content is still between $30 \%$ and $50 \%$ and varies independently of the sand fraction. The modal sizes are less distinct and generally fall within the fine silt size. The median diameters are variable, but are usually lower than 10 . Cumulative curves tend to logarithmic shapes and are either symmetrical or show an important coarse-grained tail. Such a grain-size distribution characterizes poorly sorted to unsorted sediments, which correspond to the muddy to gravel-bearing clayey silts and silty clays.

Type 3 distribution is typical of silts having no coarse particles, a low fine sand fraction $(<20 \%)$, and a low to very low clay content $(15 \%-30 \%)$. This narrow range of grain sizes characterizes moderately sorted sediments. They are also distinguished (1) by a more distinct modal size that falls into the coarse silt class, (2) by a median diameter of about $10 \mu \mathrm{m}$, and (3) by a weak fine-grained tail and thus are positively skewed and exhibit a parabolic-shaped frequency curve.

Type 4 distribution characterizes silty sands and sandy silts. It is distinguished from type 3 distribution mainly by a higher fine sand fraction $(>20 \%)$, a more pronounced positive asymmetry and a parabolic, cumulative-frequency curve shape. Indeed, the median diameter is near the fifth coarser percentile, and the modal size is distinct and falls in the fine sand class. However, the clay content can be relatively high (up to $30 \%$ ) with respect to the high sand content and, in some samples, a second minor modal diameter appears in the important finegrained tail. Therefore, the importance of this tail implies that sorting is moderate to low.

\section{Sedimentary Structures and Interpretation}

Interpretation of the main grain-size distributions is supported by studying sedimentary structures observed from thin sections and by analyzing the associated grain-size distributions. Several examples, first from lithologic Units I and II, then from lithologic Unit III, are presented and interpreted.

Lithologic Units I and II are characterized by the alternating (on a scale of $10 \mathrm{~cm}$ to $1 \mathrm{~m}$ ) silty or clayey muds and silty clays depicted respectively by types 2 and 1 grain-size distributions, the main difference being the coarse-particle content. Commonly, these sediments are structureless or locally bioturbated. However, some distinctly laminated detrital carbonate silt beds from 1 to $5 \mathrm{~cm}$ thick can be seen, often at the contact between the muds and the clayey silts. Several oriented samples from these lithologic units are described next.

Sample 105-645D-9R-1, 142-148 cm (Pl. 1, Fig. 1) contains a muddy silt bed ( $27 \%$ sand, $28 \%$ clay) $1 \mathrm{~cm}$ thick and included 


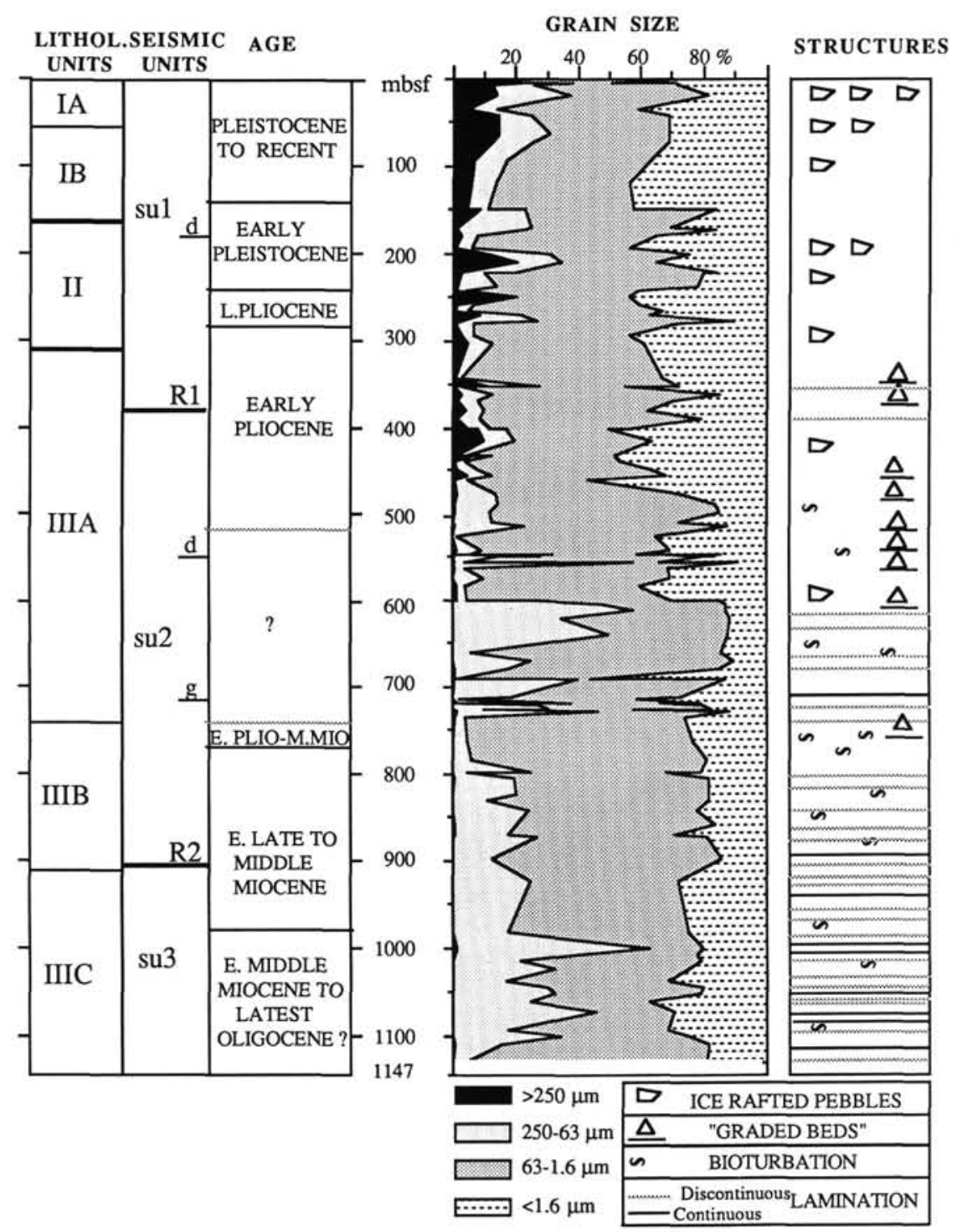

Figure 2. Lithostratigraphic summary for Site 645 showing lithologic units, seismic units, age, grain-size, and scheme of sedimentary structures.

in a clayey silt ( $1 \%$ sand, $44 \%$ clay). The muddy bed comprises scattered particles up to $3 \mathrm{~mm}$ in diameter, either quartz and feldspar grains or shale, sandstone, and minor limestone clasts; its grain-size distribution is type 2 (Fig. 6A). Both the lower and upper contacts are sharp. The clayey silt presents a type 1 distribution; it is also structureless except for elongated darker patches and a few concentrations of clean, sand-sized grains, which is indicative of bioturbation. A few outsized grains are dispersed throughout. The absence of sedimentary structures and the presence of outsized clasts exclude the hypothesis of a current influence. Moreover, the muddy silt is too thin and its upper contact too sharp to be related to some kind of gravity flow. The high range of grain sizes and the correlative low sorting (distribution type 2) with the presence of clasts of distinct nature, but with a notable amount of detrital carbonate, characterize the tills from southern Baffin Island (Fillon et al., 1981; Andrews, 1985 ) and agrees with a melting out of sediments carried by icebergs (Baker and Friedman, 1973). Thus, I interpret the thin muddy silt bed as representing a short interval of ice-rafting supply. The clayey silt presents a type 2 grain-size distribution characterized by a negatively skewed frequency curve, which is indicative of a deposition from fine-grained uniform suspension. The presence of bioturbation and the absence of dynamic structures suggest that the clayey silt lithology was deposited in quiet water from hemipelagic suspension or from more dense nepheloid layers because the frequency curve toward the finesized classes presents a logarithmic shape (Rivière, 1977). However, the presence of a few coarse grains may indicate a weak proportion of ice-rafted detritus.

Sample 105-645B-17X-1, 95-101 cm (Pl. 1, Fig. 2) was taken from an interval described as interbedded silty clays, clayey silts, and silty muds between a homogeneous detrital carbonate silty mud overlain by a mottled clayey silt. From the bottom to the top of the thin section, a succession of four intervals with gradational contacts is characterized by (1) a silty mud with a low sand-sized fraction, (2) a homogeneous clayey silt, (3) a sandy mud with limestone clasts (26\% carbonate) up to $4 \mathrm{~mm}$ wide, grading upward through indistinct laminae in (4) a clayey silt ( $10 \%$ sand) characterized by a parallel bedding and a few outsized clasts (16\% carbonate). Intervals 3 and 4 are depicted by grain-size distribution types 2 and 1 , respectively, near those of the previous example (Fig. 6A). Therefore, the same interpre- 


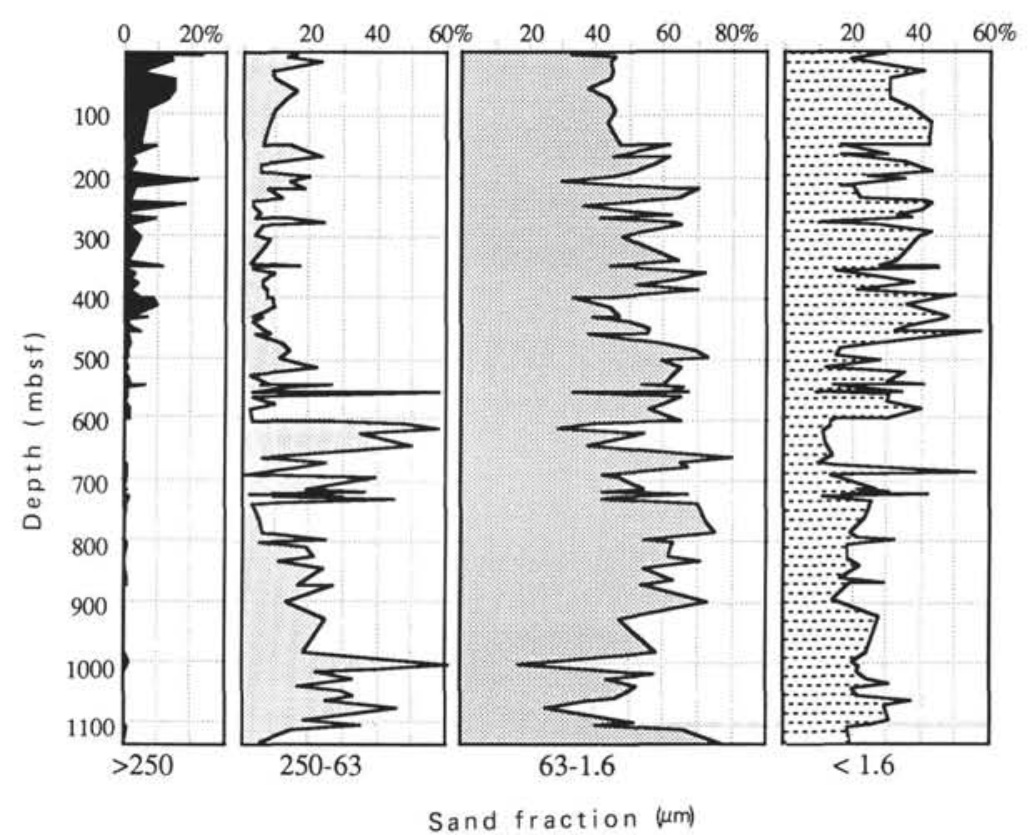

Figure 3. Coarse particle ( $>250 \mu \mathrm{m})$, fine sand, silt, and clay $(<1.6 \mu \mathrm{m})$ contents at Site 645 .

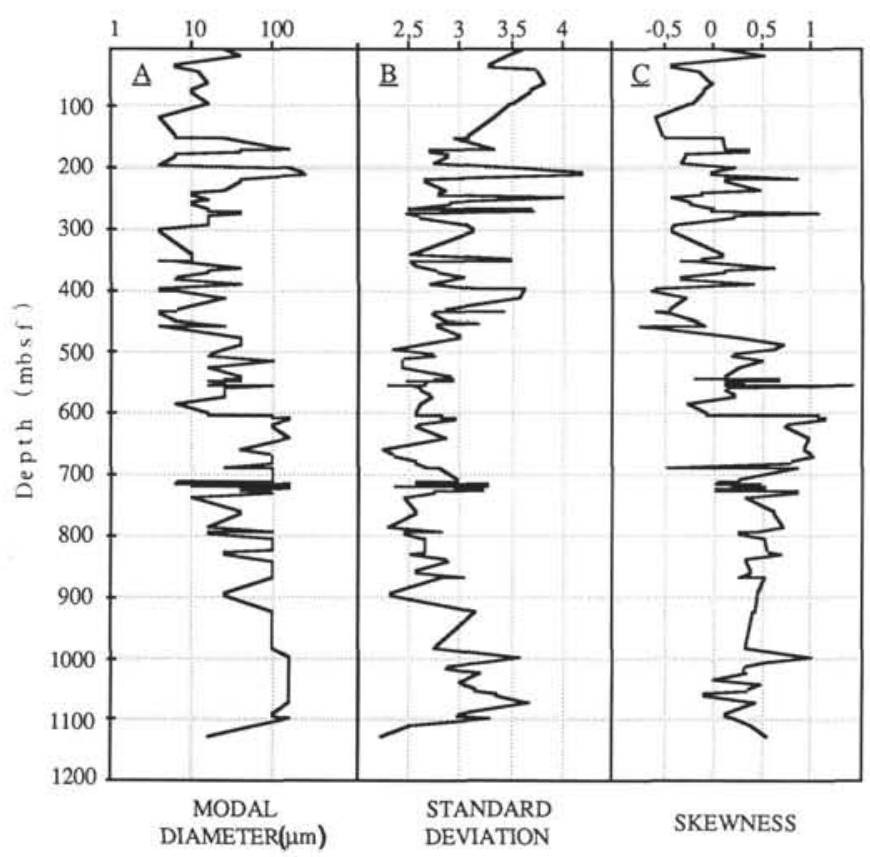

Figure 4. Vertical variation of modal diameter, standard deviation, and skewness at Site 645.

tation is suggested, i.e., a deposition of suspension more or less loaded by ice-rafted detritus. However, this sample is distinguished by the occurrence of parallel bedding having distinct, very thin beds. This parallel bedding is not related to current action (1) because each individual bed is not well sorted but may contain outsized grains and (2) because the upper interval contains two thin beds that are distinguished from the others by a concentration of dark grains, thus indicating that these layers may share a different origin. This parallel bedding indicates a fluctuation in both the amount and nature of sediment supply from ice rafting. A similar interpretation is suggested to explain,

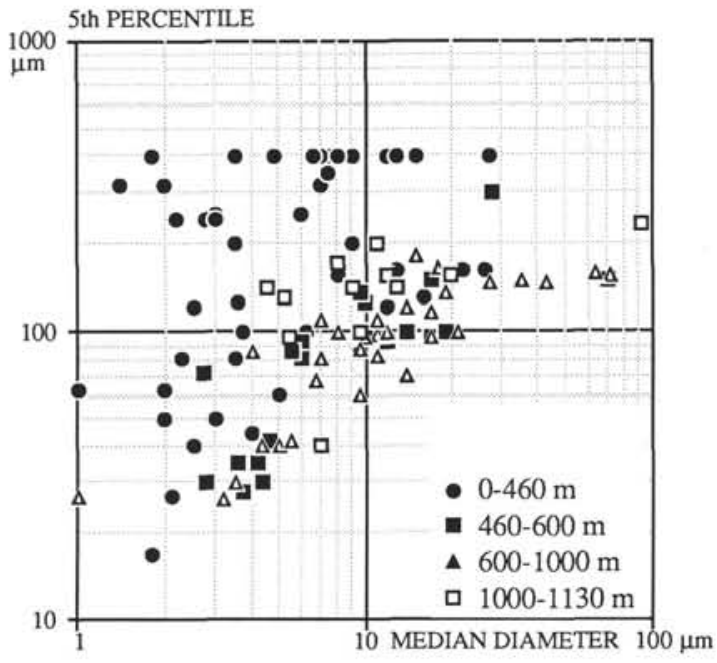

Figure 5. Diagram of the fifth coarser percentile and median diameters for samples from Site 645 .

by a decrease of ice-rafted sediment supply, the cycles frequently observed from detrital carbonate silty muds or muddy sands, which are lighter in color, massive or indistinctly laminated, and color banded, to silty muds and clayey silts containing a few outsized clasts that are a darker shade.

Sample 105-645B-11X-2, 53-60 cm (Pl. 1, Fig. 3) was taken from a short interval characterized by interbedded detrital carbonate silt and clay at the top of a muddy sand and at the base of a clayey mud. The thin section contains six graded beds of comparable thickness. Each bed starts with a massive detrital carbonate silt (the lower contact is sharp). Upward, thin, continuous silt and clay laminae become clear; then, the silt laminae become thinner and pass out of sight, while a homogeneous clay appears. Out sized particles in a clayey matrix characterize the top of the bed. Such a succession of sedimentary structures clearly indicates fine-grained turbidites (Piper, 1978; Stow and Piper, 1984; Cremer and Stow, 1986). These are also similar to 

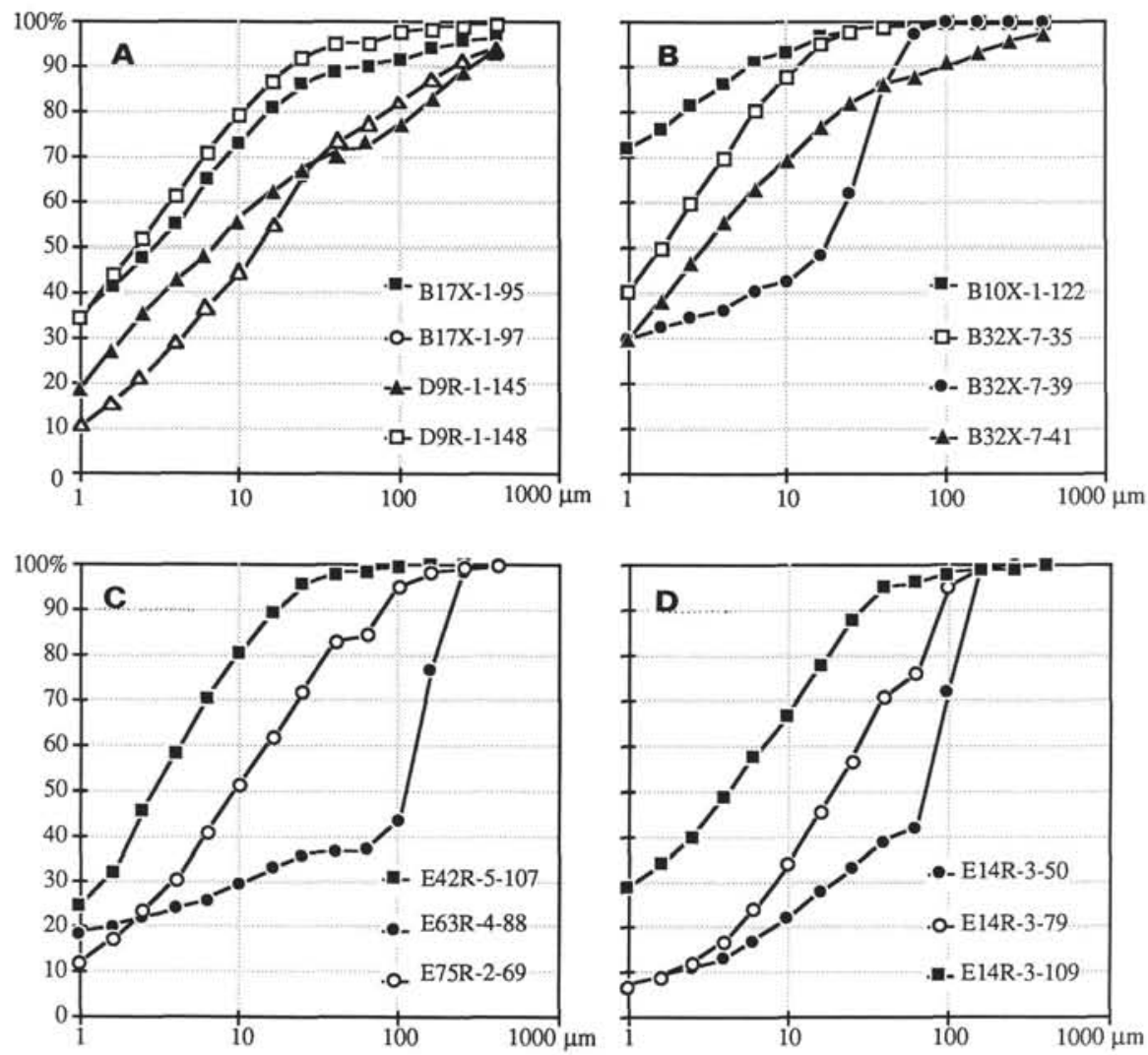

Figure 6. Examples of grain-size curves of thin-section subsamples from Site 645, showing grainsize distribution type 1 (square); type 2 (triangle); type 3 (open circles); and type 4 (closed circles).

those described from the levees of NAMOC (Chough and Hesse, 1987; Hesse and Chough, 1980). What distinguishes these turbidites is the presence of the outsized clasts at their top. These clasts are from either crytalline rocks, such as the granitic pebble at the top of the fifth bed, or from sedimentary rock, such as the sandstone clast that punchs down the silt-clay laminae of the upper turbidite. According to their location, these muddy beds are related to the interturbidite interval characterized, in this case, by an ice-rafted supply mixed with fine hemipelagic sediment. Thus, the turbiditic clayey interval is more fine-grained than the "hemipelagic" interval.

Sample 105-645B-32X-7, 35-42 cm (Pl. 1, Fig. 4) was removed from a sand-rich interval within a clayey silt; it contains two main distinct lithologies. The lower lithology is a silty mud (41 cm in Fig. 6B) having scattered clasts of quartz and feldspar grains, shale, sandstone, and minor limestone fragments $(8 \%$ carbonate). This lithology is related mainly to ice-rafted detritus. Above, the upper lithology (a clayey silt to silty clay sequence, at 39 and $35 \mathrm{~cm}$ in Fig. 6B) starts with a rather massive clayey silt, which is sharp-based and characterized by dark diagenetic patches developed within the clayey matrix that surrounds coarse, silt-sized grains. Laminae of silt cleared of the fine-grained fraction appear upward; these laminae contain more detrital carbonate grains ( $15 \%$ carbonate). However, they are very deformed by coring disturbance, which prevents a more detailed observation of the succession of structures. The thin layer, which again contains out sized grains at the top of the laminated interval, is also related to a coring artifact, owing to an intrusion of drilling mud from the edge of the core. Above this layer, the sediment is finer-grained $(50 \%<1.6 \mu \mathrm{m})$ and homogeneous; the carbonate content also decreases to $10 \%$. This upper sequence presents the characteristics of turbidites: a sharp base, a positive grading (mainly depicted by a decrease of the coarse-particle content and emphasized by the change of the grain-size distribution from type 4 to type 1; Fig. 6B), and the presence of distinct, better sorted laminae. In the former example of turbidite, the hemipelagic interval was thinner than the turbiditic one and included outsized grains. Thus, the thick, fine-grained silty clay interval at the upper part of the latter example is interpreted as part of the turbiditic interval.

Some other samples of detrital carbonate silty clay from the upper part of Hole $645 \mathrm{~A}$ also are very fine-grained (up to $76 \%$ $<1.6 \mu \mathrm{m}$; Sample 105-645B-10X-1, $122 \mathrm{~cm}$, in Fig. 6B) and contain up to $53 \%$ carbonate. These are structureless, or present a layering that can hardly be distinguished from smearing that resulted from coring disturbance. These samples are also related to deposition from dilute turbidity currents.

Lithologic Units I and II are characterized by an alternation of types 1 and 2 grain-size distribution. According to my interpretation of the samples described above, this alternation (which is mainly depicted by the coarse-particle content) can be related directly to the rate of supply of ice-rafted detritus, superimposed on persistent delivery of fine-grained sediments from dilute suspensions. The laminated silty beds are fine-grained turbidites that are frequently located at the top of muddy intervals, which shows that the beds are linked to turbidites, but continuity of sedimentary structures was not observed. Consequently, these beds were not interpreted as the top of thick turbidity current-to-debris flow sequences represented by the underlying muddy interval (Aksu, 1984), but rather as the consequence of a high rate of sedimentation upslope after an episode of major iceberg calving.

Lithologic Unit III is characterized by the absence of grainsize distribution type 2 under 600 mbsf. A few samples show distribution type 1; grain-size distribution type 4 dominates type 3 slightly. Sediments from lithologic Unit III also are de- 
picted by laminations, which become more pervasive and distinct downhole (Fig. 2). The laminations are less distinct within the clayey silts (which are strongly bioturbated) than in the silty and muddy sands, among which some intervals are thinly interlayered. Thin section observations confirm these characteristics.

Sample 105-645E-63R-4, 88-94 cm (Pl. 2, Fig. 1), was taken from thinly interbedded muddy silts and silty sands. The thin section shows a distinct parallel lamination. At smaller scale (Pl. 2, Fig. 2), the lamination is less distinguished. The fine sand-sized grains touch one another and only the elongated particles are parallel to the bedding. This structure and the grainsize distribution (Fig. 6C) are indicative of the influence of a current unable to carry medium sand or to sort fine sand by removing silt and mud; only the pore space contains fine-grained sediment.

Sample 105-645E-75R-2, 69-74 cm (Pl. 2, Figs. 2-4) comes from a slightly bioturbated silt interbedded with silty sand. This finer-grained sediment is less distinctly laminated; its structure is characterized by discontinuous lenticular beds of moderately sorted silt, surrounded by clayey intervals where plates of mica are parallel to the bedding. In some places, this organization has been obviously destroyed by bioturbation. The grain-size distribution of such a sample (Fig. 6C), although it includes the silty and clayey beds, shows good sorting and low clay content. Such characteristics are also related to current influence, but of lower and less constant intensity than for the former example.

Sample 105-645E-42R-5, 107-113 cm (Pl. 2, Fig. 5) was removed from a clayey interval that is faintly laminated and slightly bioturbated. Indeed, the grain-size distribution of this sample is type 1 (Fig. 6C,) but the clay content is not high. The thin section does not reveal small-scaled sedimentary structures, but does reveal gradual changes in grain-size. At a smaller scale (Pl. 2, Fig. 6), the sediment apparently contains numerous touching-to-coalescing balls about $0.5 \mathrm{~mm}$ wide. These are more or less dark, according to their clay content and are surrounded in places by a siltier matrix or concentrated within formless pockets. These balls are interpreted as micropellets and indicate that this finer-grained sediment is more strongly bioturbated.

These sandy to clayey silt lithologies are interlayered with sharp bed contacts or occur within lithologic Unit III in massive sequences having gradational contacts of either positive or negative grading. These bedding characteristics, the presence of parallel laminations with no consistent sequence of structure, a distinct fine tail on grain-size curves, a moderately good sorting of the coarser grains, a lack of outsized particles, and pervasive bioturbation make these sediments strongly resemble the contourites described by Faugères et al. and Gonthier et al. (1984) and defined by Stow and Piper (1984) as silty-sandy contourites. Because the maximum grain size is included in the fine sand class, the contour currents were not necessarily very strong. Indeed, a current reaching mean velocity of 20 to $30 \mathrm{~cm} / \mathrm{s}$, which is frequently observed from modern contour currents (Hollister and McCave, 1984), is capable of carrying grains having a diameter corresponding to the maximal modal size observed (Fig. 4A). Moreover, a pronounced current influence is supported by interpreting the migrating depositional ridges located upslope as current drift building (Arthur et al., this volume, but see Hiscott et al., this volume, for an alternative interpretation).

Thus, the grain-size variation that overall depicted a finingupward sequence from lithologic Subunit IIIC to Subunit IIIB is related to a weakening of the bottom-current influence.

Bioturbated and vaguely to distinctly laminated silty sands and sandy silts also dominate in the bottom part of lithologic Subunit IIIA (600-730 mbsf). These beds alternate with minor silty clays in $10-\mathrm{cm}$ - to 2 -m-thick sequences with mostly gradational contacts, which is shown by the nearer samples collected in Core 105-645E-33R (714-724 mbsf). These sediments, which also are depicted by types 3 and 4 grain-size distibution, are sim- ilar to those of Subunit IIIB and thus are explained by a new episode of strong current influence.

The sharp increase in clay content and the appearance of a few out-sized grains at 600 mbsf indicate at least a weakening of the current influence concomitant with the first notable contribution of ice rafting. However, the upper part of lithologic Subunit IIIA (Fig. 2) contains several positively graded muddy sand to sandy silt beds that are either sharp-based or start by a short coarsening-upward interval and that include outsized shale clasts. These beds have been tentatively associated with gravity flows. Nevertheless, post-cruise study of some "graded beds" was not able to demonstrate grading (Hiscott et al., this volume). In contrast, a 60-cm-thick bed from Core 105-645E-14R-3, described as graded silty mud, does grade from a silty mud to a clayey silt (Fig. 6D). The change from parabolic- to hyperbolicshaped grain-size curves agrees with a turbidite sequence, but contrary to what one may expect from a turbidite, the proportion of mica plates decreases upward, while the number of outsized quartz clasts increases. Moreover, the basal sample, a micaceous silty sand, presents a grain-size distribution and grainshape characteristics (Cremer and Legigan, this volume) similar to those of the underlying inferred sandy contourites (Fig. 6C), which are also rich in mica plates.

Therefore, I favor the hypothesis that contour currents were still active, at least from time to time, during deposition of lithologic Subunit IIIA, but that ice rafting was the dominant transport agent for the outsized grains. Such an interpretation explains that outsized ice-rafted particles can be either concentrated like a lag deposit at the base of the graded beds during an episode of strong current influence, or scattered throughout the beds when the current becomes weaker and when the deposition rate of current-transported grains increases. I also interpret the thick ungraded, or inversely graded, sequences of muddy silt having a low coarse-particle content (520-460 mbsf) as contourites. Above this range, the coarse-particle and clay contents both increase and mark a higher contribution of ice rafting.

Moderately sorted silts and sandy silts, positively skewed and characterized by a low coarse-particle content, were sampled at 390,360 , and 276 mbsf. According to seismic interpretation, which indicates a bottom-current influence up to the base of lithologic Unit I, they are tentatively interpreted as resulting from episodes of more pronounced current influence. Finally, no contour current imprint can be deduced from grain-size characteristics in lithologic Unit $\mathrm{I}$.

\section{SITE 646, LABRADOR SEA}

Site 646 was drilled in the Labrador Sea off the southern coast of Greenland at a water depth of $3450 \mathrm{~m}$ (Fig. 1). The site is located on the northern flank of a subsidiary ridge of the Eirik drift sequence, which was built off the southern tip of Greenland under the influence of the Norwegian Sea Overflow Water (Jones et al., 1970). The main objective of drilling at this site was to document the history of sedimentation as a record of the initiation and variations through time of bottom currents in the North Atlantic.

The cored section consists of dominantly fine-grained, terrigenous sediments (Fig. 7). Lithologic Unit I (0-236 mbsf; late Pliocene to Holocene) is characterized by scattered coarse particles up to cobble size; its base is defined by the disappearance of this material. In Subunit IA, silty clays and clayey sediments containing variable amounts of biocarbonate (up to $40 \%$ ) and siliceous $(<10 \%)$ skeletons, commonly structureless or bioturbated, alternate in fine-scaled cycles with minor lithologies that are (1) silty and clayey muds, (2) layers consisting of about $50 \%$ detrital carbonate, either massive or laminated, and (3) laminated siliceous silty beds. Subunit IB is characterized by a higher content of granule-sized particles and the disappearance of detrital 


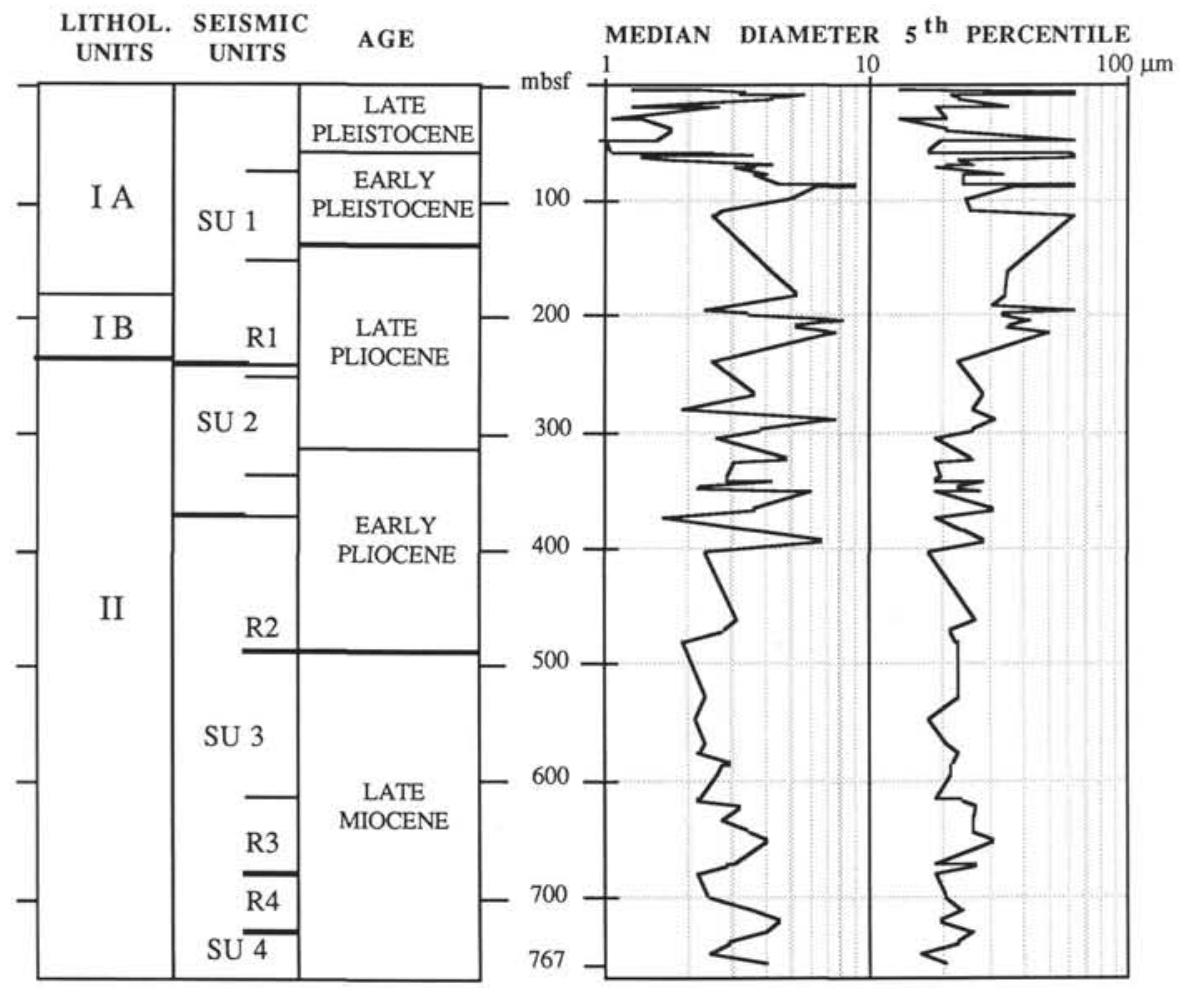

Figure 7. Lithostratigraphic summary for Site 646 showing lithologic units, seismic units, age, median diameters, and fifth coarser percentile.

carbonate beds. Lithologic Unit I corresponds to seismic Unit 1, depicted by high-amplitude reflectors that are parallel to subparallel to the seafloor. Lithologic Unit II (236-767 mbsf; of late Miocene to late Pliocene age) is dominated by clay-rich sediments that, except for the laminated silt beds above $400 \mathrm{mbsf}$, show little variation of either texture or sedimentary structure. However, a higher proportion of nannofossils was observed at 310-470 mbsf. Lithologic Unit II includes three distinct seismic units. Seismic Unit 2 is characterized by a lenticular shape and migrating waves that indicate strong bottom-current influence; seismic Units 3 and 4 present less continuous and lower-amplitude reflectors, except for the regional reflector R2 (502 mbsf) and the R3/R4 doublet (680 and 730 mbsf).

\section{Grain-Size Characteristics}

The study of grain sizes for samples collected from dominant lithologies, which excludes the laminated layers, confirms the fine-grained character of sediments at Site 646 . The median diameter (Fig. 7) rarely exceeds $5 \mu \mathrm{m}$ and can be less than $1 \mu \mathrm{m}$. A sand content of over $10 \%$, which warrants the term mud, is found in only a few samples of lithologic Unit I. However, the boundary of lithologic Units I and II is effectively marked by an increase of the $>63-\mu \mathrm{m}$ fraction, which is strictly less than $1 \%$ in lithologic Unit II. Using a silt-clay limit of $1.6 \mu \mathrm{m}$, most of the sediments can be described as clayey silts; only the finergrained sediments above 70 mbsf are silty clays. The shapes of the grain-size curves (Fig. 8) show a little variation, mostly about the grain-size distribution of types 1 and 3 , which were described for Site 645. As the median diameter increases, the curves tend to a parabolic shape depicted by a more distinct fine tail and positive skewness. However, more hyperbolic-shaped and positively skewed curves characterize the finest-grained sediments of lithologic Unit I, even if they contain sand-sized material.

In spite of this apparent homogeneity, distinct characteristics can be defined for each lithologic unit.

\section{Lithologic Unit I}

Samples from lithologic Unit I are scattered on the fifth percentile-median diameter diagram (Fig. 9). The low values of median diameter correspond to high or low values of fifth percentile. This is characteristic of clayey sediments interpreted as issued from deposition of fine-grained hemipelagic suspension with variable amounts of coarse outsized material, mainly detrital with minor biogenic (Sample 105-646A-6H-2, $84 \mathrm{~cm}$, in Fig. $8 \mathrm{~A})$. Conversely, higher median diameters $(>3 \mu \mathrm{m})$ can correspond either to relatively low fifth $(<30 \mu \mathrm{m})$ percentiles that characterize better sorted and positively skewed clayey silts or silts with no outsized grains (Sample 105-646A-1OH-2, $115 \mathrm{~cm}$, in Fig. 8A), or to higher fifth percentiles $(>30 \mu \mathrm{m})$ that characterize similar clayey silts, but with slightly higher clay and coarseparticle contents, up to granule size (Sample 105-646B-23X-4, $92 \mathrm{~cm}$, in Fig. 8A). These sediments can be interpreted as resulting from partial winnowing of the fine-grained fraction under the influence of a current. Subunit IB is characterized by the three basal samples that contain the highest coarse-silt fraction of the section. However, these clayey silts include a low sand content $(1.3 \%-1.9 \%)$. The upper samples from lithologic Subunit IB are finer-grained clayey silts. The boundary between lithologic Subunits IB and IA cannot be seen clearly, and grain size defines only one major fining-upward sequence throughout lithologic Unit I. However, an interval of better sorted clayey silts can be identified before a decrease in grain size that occurs near the early-late Pleistocene boundary.

\section{Lithologic Unit II}

On the basis of the vertical evolution of the median diameter (Fig. 7), lithologic Unit II was divided into two subunits, with the limit located at a minimum diameter value that was observed at 480 mbsf near the Miocene/Pliocene boundary and regional reflector R2. Biogenic content (mainly nannofossils) was 

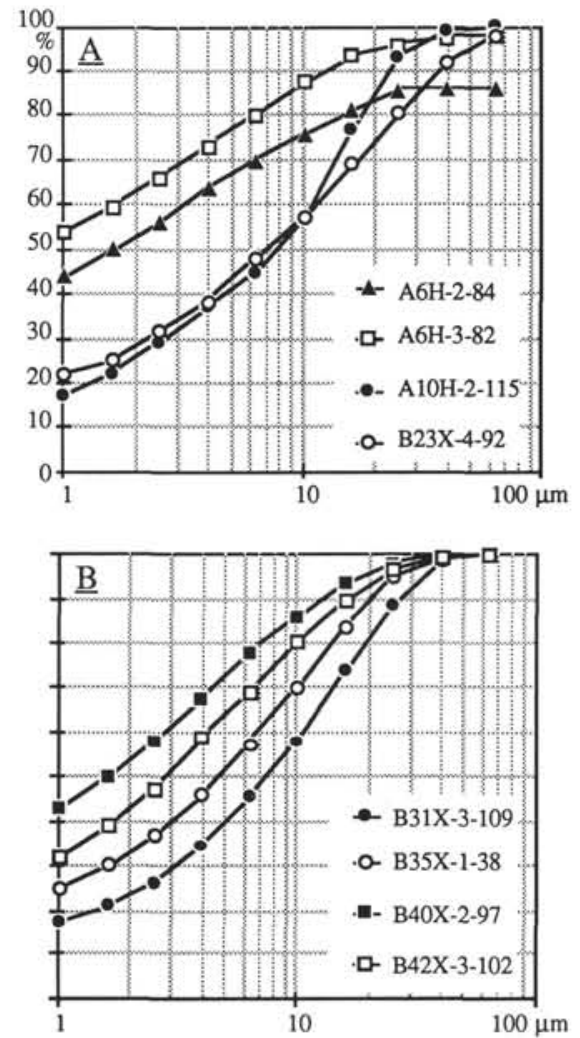

Figure 8. Examples of grain-size curves of dominant lithologies from Site 646. A. Lithologic Unit I. B. Lithologic Unit II.

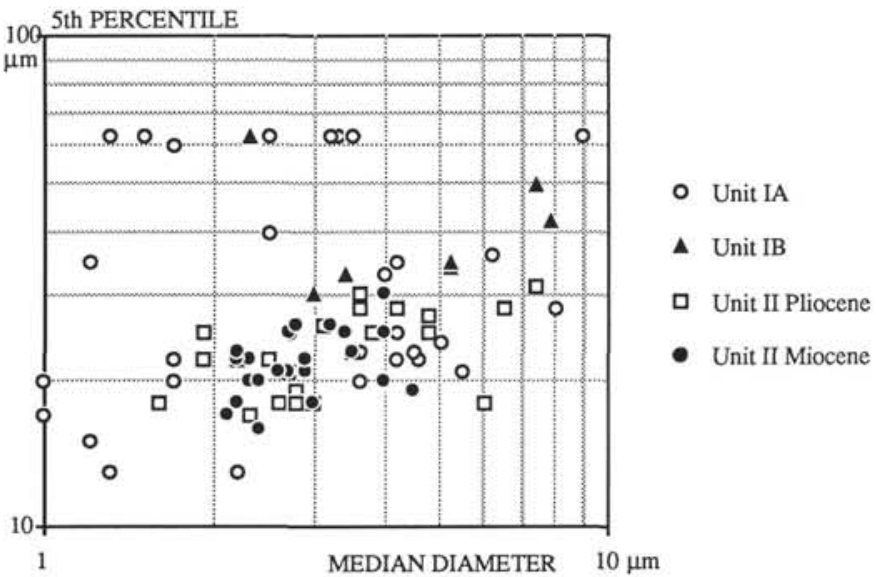

Figure 9. Diagram of fifth coarser percentile and median diameter from samples of dominant lithologies at Site 646.

deduced from the carbonate content. The latter, which is less than $5 \%$ at the top of the upper subunit, increases downward to exceed $20 \%$ slightly at the base of the upper subunit; in the lower subunit, it varies rapidly between $0 \%$ and $17 \%$. These low values do not warrant use of the qualifier nannofossil.

The upper subunit is characterized by important variations of the median diameter from sample to sample. The fifth coarser percentile fluctuates in the same way, but with a lower amplitude and does not exceed $30 \mu \mathrm{m}$. The finer-grained sediments are clayey silts having symmetrical grain-size curves (Fig. 8B); the coarser-grained sediments are less clayey and better sorted silts with distinct positively skewed grain-size curves. The latter first appear at $\mathbf{3 9 5}$ mbsf, where the earliest laminated silt layer was observed.

The lower subunit, from the bottom of the hole up to 480 mbsf, can be globally characterized by a fining-upward sequence; the sediments also grade from clayey silts having a slight positive skewness to more clayey silts with symmetrical grain-size curves that indicate a more pronounced hyperbolic shape toward the coarse sizes. In detail, the highest values of mean diameter occur at 720 and 650 mbsf on both sides of an interval of finer-grained sediments. The mean diameter regularly decreases uphole from $650 \mathrm{mbsf}$; at this depth the fifth coarser percentile reaches a maximum value similar to those of the upper lithologic subunit. These variations occur near the calculated depth of the reflector R3/R4 doublet (680 and $730 \mathrm{mbsf}$; Arthur et al., this volume).

According to the characteristics described above and their location on the fifth coarser percentile-median diameter diagram, the sediments of lithologic Unit II indicate a narrow range of grain-size distributions (Fig. 8B). These are intermediate between typical decantation in quiet water of uniformly fine-grained suspension and deposition of graded suspension under a strong bottom-current influence.

\section{Sedimentary Structures and Interpretation}

As for Site 645 , the study of finely scaled sedimentary structures within the oriented samples, mainly collected from lithologic Unit I, allows us to more accurately interpret the distinct lithologies and to relate them to ice-rafted detritus, silty contourites, and detrital carbonate turbidites, as shown by the following description of several examples.

Sample 105-646A-6H-2, 84-91 cm (Pl. 3, Fig. 1) is an example of a clayey mud bed having rather sharp lower and more transitional upper contact, which occurs in a sequence of silty clay. The thin section shows a clayey matrix $(50 \%<1.6 \mu \mathrm{m})$ that includes scattered quartz and feldspar grains, shale, sandstone, and limestone clasts, and formless clay patches. A few foraminifers are present in the less coarse, particle-rich, upper part of the thin section. Such a poorly sorted, structureless sediment is interpreted as typical of rapid deposition of ice-rafted detritus.

Sample 105-646B-9H-4, 57-64 cm (Pl. 3, Fig. 2) is an example of the detrital carbonate silty beds, only present in Subunit IA, that are commonly depicted by sharp-based, detrital carbonate silt laminae and a bioturbated gradational upper contact. At the bottom part of the thin section, a structureless clayey silt includes a few carbonate skeletons and scattered outsized particles. The latter are more numerous and the sediment more clayey at the contact of the detrital carbonate bed (Pl. 3, Fig. 5), which indicates hemipelagic sediments with an increasing amount of ice-rafted detritus. This sharp-based bed starts with a laminated clayey silt interval $(22 \%<1.6 \mu \mathrm{m})$. Two thicker silt laminae appear upward and show microripples interlayered with clayey laminae; then, the silt laminae become thinner and pass out of sight, while the sediment grades to a homogeneous silty clay. Such a succession of structure (throughout laminated silt, interlayered silt and clay laminae, laminated then homogeneous clay) is consistent with a turbiditic sequence.

Sample $105-646 \mathrm{~A}-3 \mathrm{H}-4,9-14 \mathrm{~cm}$ (Pl. 3, Fig. 3) presents a similar sequence of structure. This sequence also includes a burrow that interrupts the upper laminated interval and a less-laminated basal interval that contains discontinuous patches of a silty clay. This clay is similar to the underlying one and thus related to clay rip-up clasts.

Sample 105-646B-11H-2, 30-37 cm (Pl. 3, Fig. 6), collected from the bioturbated top of a 20 -cm-thick detrital carbonate bed, only shows a silty clay in which rare disrupted silt laminae indicate a strongly bioturbated turbidite. Unfortunately, the thin sections are too small to prove the presence of multiple tur- 
biditic events in these thicker detrital carbonate beds, as has been shown by X-radiographs (Hiscott et al., this volume).

Sample 105-646A-H4-4, 71-77 cm (Pl. 4, Fig. 1) contains one of the siliceous silt layers, 1- to 5-cm-thick, that is characterized by distinct laminations and either sharp or gradational contacts. This layer overlies a silty clay bearing nannofossils and foraminifers. At its lower part, the layer is characterized by a fine parallel lamination; thin laminae of cleared silt include a notable amount of heavy minerals, black grains, and minor siliceous skeletons. Upward, a more oblique stratification is depicted by microripples. Then, lamination fades while numerous pellets appear. First, these pellets are included in the oblic silt beds, then touch one another or are scattered in formless silt pockets. There is surprisingly little change in grain size from the base of the silt layer to the top of the thin section. Grain-size distribution is characterized on an average by less than $20 \%$ clay, a $20-\mu \mathrm{m}$ fifth coarser percentile, a $10-\mu \mathrm{m}$ median diameter, moderately good sorting, and positive skewness.

Similar structures are found in other laminated silty beds (Pl. 4, Figs. 2,4,5,6,7), that is, very fine-scaled parallel and cross-lamination, concentration of heavy minerals on top of the ripples, and either sharp or transitional contacts. According to these characteristics and the absence of a consistent sequence of structure, these laminated silt layers can be interpreted as having been deposited under a strong bottom-current influence.

Sample 105-646A-11H-1, 103-109 cm (Pl. 4, Fig. 3) includes one of the 1-cm-thick graded silt beds observed in a clayey silt sequence. This bed, at the lower part of the thin section, is characterized by distinct silt laminae, which are wavy at a very fine scale and the spacing of which decreases upward. This feature resembles the structure of the laminated turbidite interval. However, there is no significant change in grain size throughout the section; the apparent grading is linked only to change in grain arrangement. Moreover, contrary to what was observed in the turbidite sequences, the spacing of silt laminae decreases upward. Therefore, I also interpret such a sequence as a contourite that may be related (but at a larger scale) to the changes observed in the microripples.

The samples from thin sections have been plotted on a diagram depicting the fifth coarser percentile and median diameter, according to the inferred transport agent (Fig. 10). Sediments called "hemipelagite" refer to structureless or indistinctly laminated and bioturbated sediments that bear biogenic skeletons (Pl. 3, Fig. 4). Inferred laminated silty contourites are well grouped and characterized by the highest median diameters. Ice-rafted detritus are clearly distinguished by the highest fifth percentiles. The detrital carbonate silts from the bottom part of these turbidites have slightly lower median diameters and higher fifth percentiles than the silty contourites; this indicates they are less sorted. The detrital carbonate silty clays from the top of turbidites are the finest-grained ones, according to deposition during the final stage of decantation of the turbiditic cloud. The "hemipelagic" sediments are distributed as detrital carbonate turbidites. Thus, they can be related to true hemipelagic decantation for finer-grained sediments or related to sediments weakly, then more strongly, winnowed by bottom current as their median diameter increases. Moreover, as shown by piston cores from Eirik Ridge (Chough and Hesse, 1985), the finegrained contourites are distinguished from turbidites by a high degree of bioturbation that preserves only a few discontinuous silt beds.

By studying these thin sections, we can understand the significance of vertical evolution of grain-size characteristics in the cored section.

The clayey silts of lithologic Unit II are characterized by (1) a low sand fraction, (2) a variable amount of biogenic skeletons, and (3) the absence of detrital carbonates. Thus, the high values of median diameter observed near the bottom part of the hole

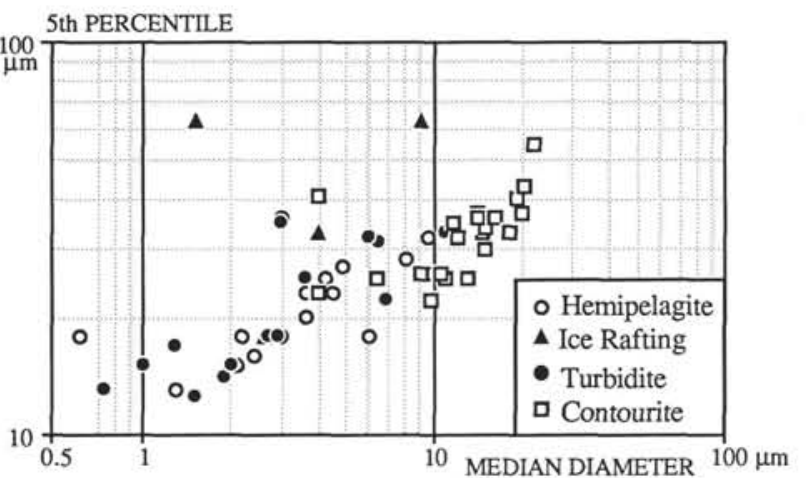

Figure 10. Diagram of fifth coarser percentile and median diameter from thin-section samples with the inferred settling processes.

can be related to pronounced current influence; however, this influence would have been highest just above the R3/R4 doublet, as shown by the higher values of the fifth coarser percentiles. Afterward, the current influence weakens up to the Miocene/ Pliocene boundary. At this depth, near the R2 reflector, an increase of the median diameter again may indicate a slight bottom-current influence during depositon of nannofossil-rich clayey silts. Then, the earliest observed bed of silt contourite appears at 395 mbsf, which marks strong winnowing by bottom currents. Through the top of lithologic Unit II, this pronounced but highly variable current influence follows up; indeed, this interval corresponds to the contourite drift-shaped seismic Unit 2.

The appearence of out-sized grains at the bottom of lithologic Unit I marks the initiation of a supply by ice rafting of terrigenous material. However, the low coarse-sized fraction in samples from the base of lithologic Unit I goes against high median diameter values and moderate sorting. Later, the typical ice-rafted detritus is recovered at about the same depth as the detrital carbonate turbidites (190 mbsf). Moreover, contourite silty beds are still present, particularly in the interval at 70 to 120 mbsf, and are characterized by high median diameters. All of which indicates that bottom currents were still active up to the early-late Pleistocene boundary. Thus, the unconformity at the top of seismic Unit 2 (R1 reflector) and the change of this reflector's configuration may be related to a change in the path or to a higher velocity of bottom currents. However, this change may be only the consequence of ice-rafting initiation, which increases the amount of detrital particles apt to be carried by bottom currents. During the late Pleistocene, current influence was only perceptible during short episodes; a decantation of hemipelagic suspension, more or less laden by ice-rafted detritus, was the dominant settling process.

\section{DISCUSSION}

The grain sizes and microstructures observed at Sites 645 and 646 indicate that sedimentation processes were similar at the two sites from three dominant agents: ice rafting, turbidity currents, and contour currents.

Ice-rafted detritus are commonly distinguished by the contribution of out-sized clasts in a fine-grained matrix. The first occurrences of ice-rafted detritus at both sites, deduced from visual core description (Arthur et al., 1987), were confirmed: a minor contribution as old as the late Miocene (at $600 \mathrm{mbsf}$ ) and the first major contribution as early as $3.5 \mathrm{Ma}$ at Site 645 , and initiation of ice rafting at about $2.5 \mathrm{Ma}$ at Site 646 .

The identified turbiditic sequences are restricted to detrital carbonate, thin-bedded turbidites from Pleistocene. These turbidites have similar characteristics at both sites (as well as at Site 647; see Hiscott et al., this volume) and are identical to those described from the NAMOC levees. (Latouche and Parra, 1979; 
Hesse and Chough, 1980). In the cycles depicted by lithologic variations, these turbidites are commonly observed in the same intervals as the ice-rafted detritus. Increased dolomite from the last glacial stage also was observed in cores from the Labrador Sea (Latouche and Parra, 1979). A high proportion of limestone clasts also characterized ice rafting at Site 645 , but these are rare at Site 646. Therefore, the initiation of gravity flows and the activity of NAMOC appears linked to episodes of high terrigenous supply by ice rafting (Chough and Hesse, 1987). The presence of detricarbonate turbidites at Site 646, the opposite of icerafted detritus of mafic rocks, is related to spillover sediments from NAMOC.

At Site 646, where typical contourites were expected, the sediments are fine-grained and show only a few sedimentary structures related to episodes of pronounced bottom-current influence. In contrast, at Site 645 an unexpectedly strong bottomcurrent influence was suggested to explain the presence of pervasive lamination in the coarser-grained sediments. This is related to the differences between muddy contourites and silty-sandy contourites (Stow and Piper, 1984). The former most closely resemble hemipelagites and are fine-grained, mixed biogenic and terrigenous sediments, strongly bioturbated, that include rare, laminated, coarser layers. These usually constitute the sediment drifts of the North Atlantic and are mainly identified by seismic characteristics (see the bibliography in Stow and Holbrook, 1984). Being coarser-grained, the latter imply the action of a strong bottom current. This occurs in more restricted, settling environments, such as the southern Iberian margin, where the currents linked to the outflow of Mediterranean water have molded; as they weaken, the terrigenous sediments in lag deposits, sand dunes, sediment drifts, and mud waves (Faugères et al., 1984, 1985). The presence of sandy contourites at the base of the Baffin Island slope suggests an important southward-directed flow, probably of arctic water masses to the Labrador Sea, up to the early Pliocene.

\section{ACKNOWLEDGMENTS}

This research was funded by the Centre National du Recherche Scientifique.

\section{REFERENCES}

Aksu, A. E., 1984. Subaqueous debris flow deposits in Baffin Bay. Geomar. Lett., 53:331-348.

Andrews, J. T., 1985. Grain-size characteristics of quaternary sediments, Baffin Island region. In Andrews, J. T. (Ed.), Quaternary Environments, Eastern Canadian Arctic, Baffin Bay and Western Greenland: Winchester (Allen and Unwin), 5:125-153.

Baker, S. R., and Friedman, G. M., 1973. Sedimentation in an arctic marine environment: Baffin Bay between Greenland and the Canadian arctic archipelago. Geol. Surv. Can., 71-23:471-498.

Chough, S. K., and Hesse, R., 1980. The Northwestern Atlantic MidOcean Channel of the Labrador Sea: III, Head spill vs. body spill deposits from turbidity currents on natural levees. J. Sediment. Petrol., 50:227-234.
1985. Contourites from Eirik Ridge, south of Greenland. Sediment. Geol., 41:185-199.

1987. The Northwestern Atlantic Mid-Ocean Channel of the Labrador Sea: V, morphology, sedimentary facies, stratigraphy and processes of a giant deep-sea channel. Can. J. Earth Sci, 24:15951624.

Cremer, M. and Stow, D.A.V., 1986. Sedimentary structures of finegrained sediments from the Mississippi fan: thin-section analysis. In Bouma, A. H., Coleman, J. M., et al., Init. Repts. DSDP, 96: Washington (U.S. Govt. Printing Office), 519-532.

Faugères, J. C., Gonthier, E., and Stow, D.A.V., 1984. Contourite drift molded by deep Mediterranean outflow. Geology, 12:296-300.

Faugères, J. C., Frappa, M., Gonthier, E., and Grouset, F., 1985. Impact de la veine d'eau mediterranéenne sur la sedimentation de la marge sud et ouest iberique au Quaternaire recent. Bull. Inst. Géol. Bassin d'Aquitaine, Bordeaux, 37:259-287.

Fillon, R. H., Miller, G. H., and Andrews, J. T., 1981. Terrigenous sand in Labrador Sea hemipelagic sediments and paleoglacial events on Baffin Island over the last 100,000 years. Boreas, 10:107-124.

Friedman, G. M., 1967. Dynamic processes and statistical parameters compared for size frequency distribution of beach and river sands. J. Sediment. Petrol., 37:327-354.

Gonthier, E., Faugéres, C., and Stow, D.A.V., 1984. Contourite facies of the Faro drift, Gulf of Cadiz. In Stow, D.A.V., and Piper, D.J.W. (Eds.), Fine-Grained Sediments: Deep-Water Processes and Facies. Geol. Soc. London Spec. Publ., 15:275-292.

Hesse, R., and Chough, S. K., 1980. The Northwestern Atlantic MidOcean Channel of the Labrador Sea: II, depositional of parallel laminated levee-muds from the viscous sublayer of low density turbidity currents. Sedimentology, 27:697-711.

Hollister, C. D., and McCave, I. N., 1984. Sedimentation under deepsea storms. Nature, 309:220-225.

Jones, E.J.W., Ewing, M., Ewing, J. I., and Eittreim, S. L., 1970. Influences of Norwegian Sea overflow water on sedimentation in the northern North Atlantic and Labrador Sea. J. Geophy. Res., 75: $1655-1680$.

Latouche, C., and Parra, M., 1979. La sedimentation au Quaternaire récent dans le "Northwest Atlantic Mid-Ocean Canyon," apport des données minéralogiques et géochimiques. Mar. Geol., 29:137-164.

Passega, R., 1957. Texture as characteristic of clastic deposition. AAPG Bull., 41:1952-1974.

Piper, D.J.W., 1978. Turbidite muds and silts on deep-sea fans and abyssal plains. In Stanley, D. J., and Kelling, G., (Eds.), Sedimentation in Submarine Canyons, Fans, and Trenches: Stroudsbourg, PA (Dowden, Hutchinson, and Ross), 163-176.

Rivière, A., 1977. Méthodes granulométriques: technques et interprétation: Paris (Masson).

Stow, D.A.V., and Holbrook, J. A., 1984. North Atlantic contourites: an overview. In Stow, D.A.V., and Piper, D.J.W. (Eds.), Fine-Grained Sediments: Deep-Water Processes and Facies. Geol. Soc. London Spec. Publ., 15:245-256.

Stow, D.A.V., and Piper, D.J.W., 1984. Deep-water fine-grained sediments: facies models. In Stow, D.A.V., and Piper, D.J.W. (Eds.), Fine-Grained Sediments: Deep-Water Processes and Facies. Geol. Soc. London Spec. Publ., 15:611-646.

Date of initial receipt: 6 July 1987

Date of acceptance: 24 May 1988

Ms 105B-113 


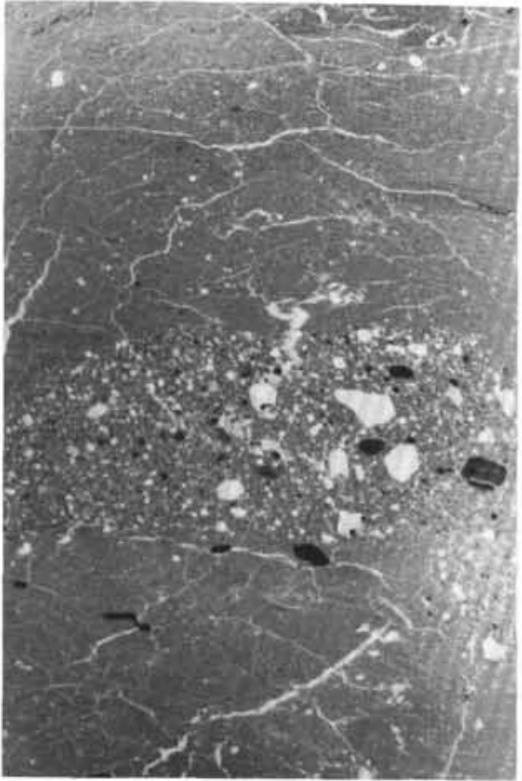

1
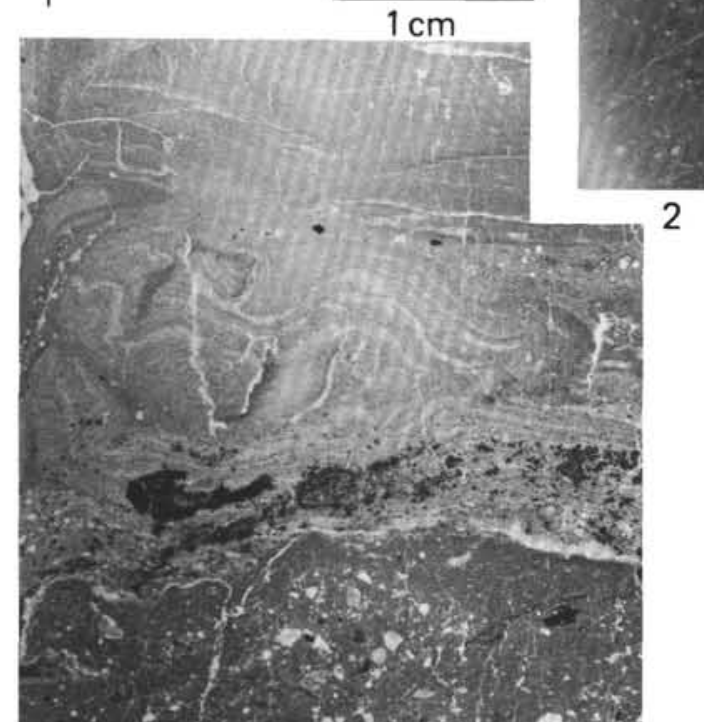

$1 \mathrm{~cm}$

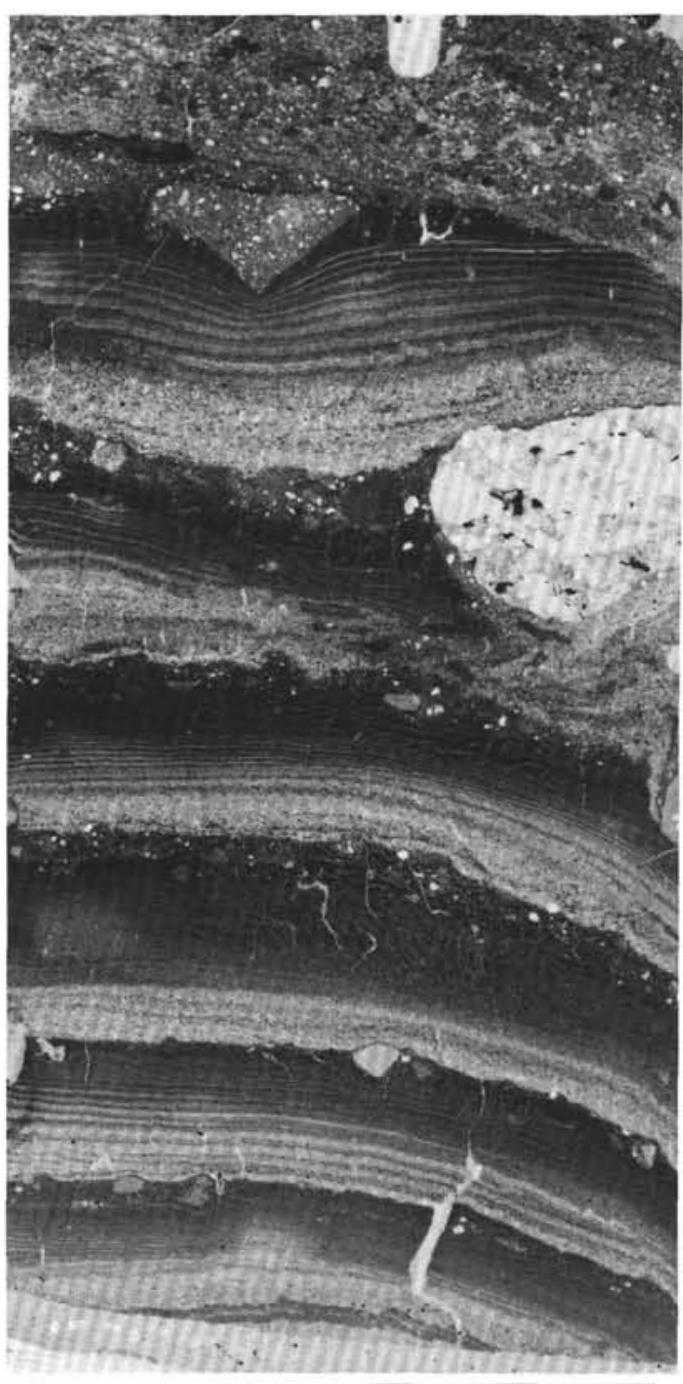

3

$1 \mathrm{~cm}$

$1 \mathrm{~cm}$

Plate 1. Photographs of thin sections from Site 645 (see description in text). 1. Sample 105-645D-9R-1, 142-148 cm; ice-rafted detritus in a single bed in a bioturbated clayey silt. 2. Sample 105-645B-17X-1, 95-101 cm; interlayered clayey silt and silty-sandy muds showing variation of ice-rafting supply. 3. Sample 105-645B-11X-2, 53-60 cm; successive, thin-bedded, detrital carbonate turbidites. 4. Sample 105-645B-32X-7, 35-42 cm; detrital carbonate turbidite overlying ice-rafted detritus. 

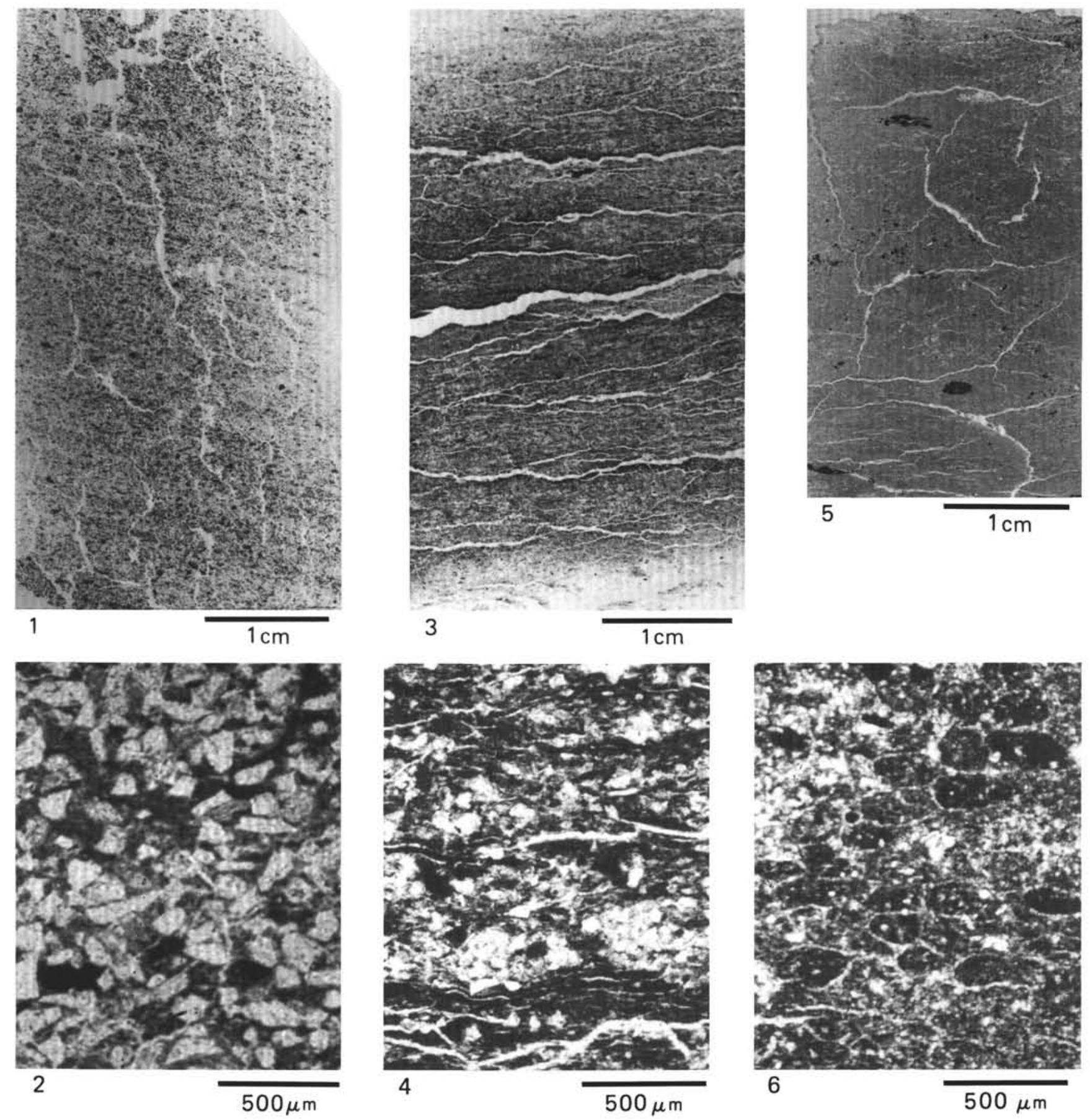

Plate 2. Photographs of thin sections from Site 645 (see description in the text). 1. Sample 105-645E-63R-4, 88-94 cm; laminated silty sand. 2. Detail of grain arrangement. 3. Sample 105-645E-75R-2, 69-74 cm; indistinctly laminated silt. 4. Detail showing discontinuous silty and clayey laminae. 5. Sample 105-645E-42R-5, 107-113 cm; structureless clayey silt. 6. Detail showing micropellets. 


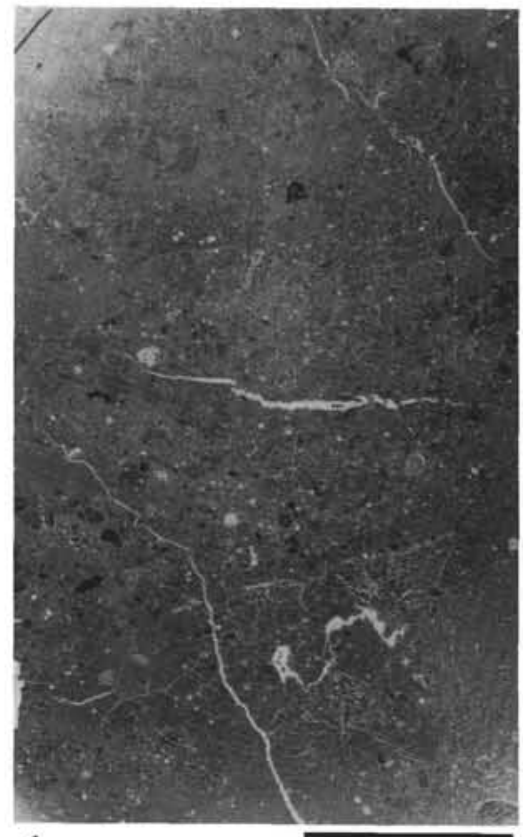

1

$1 \mathrm{~cm}$

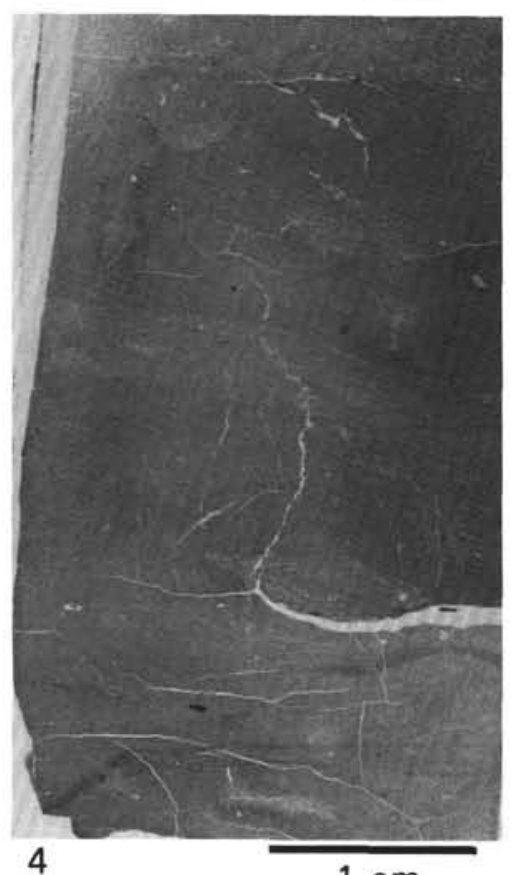

$1 \mathrm{~cm}$

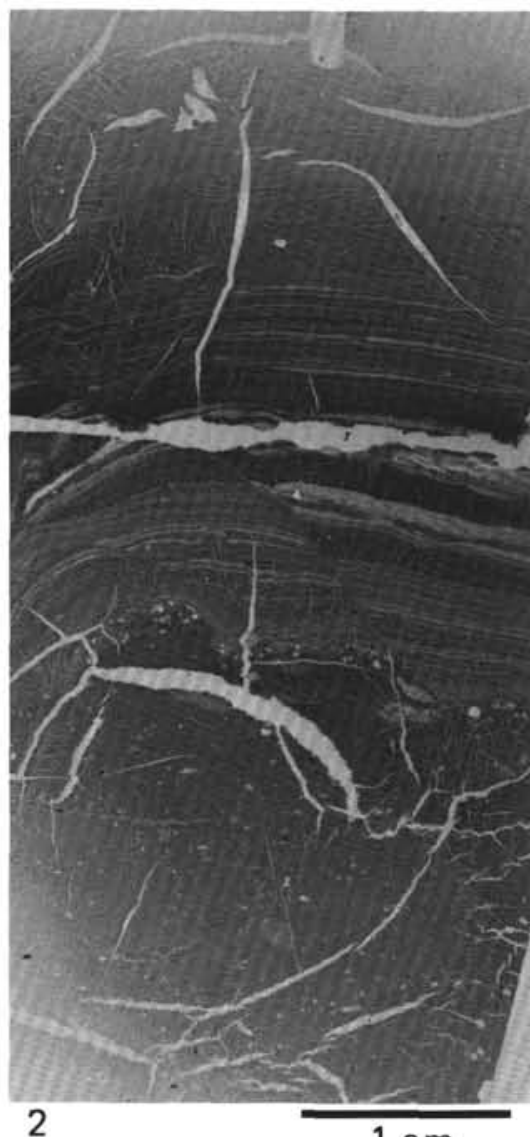

$1 \mathrm{~cm}$

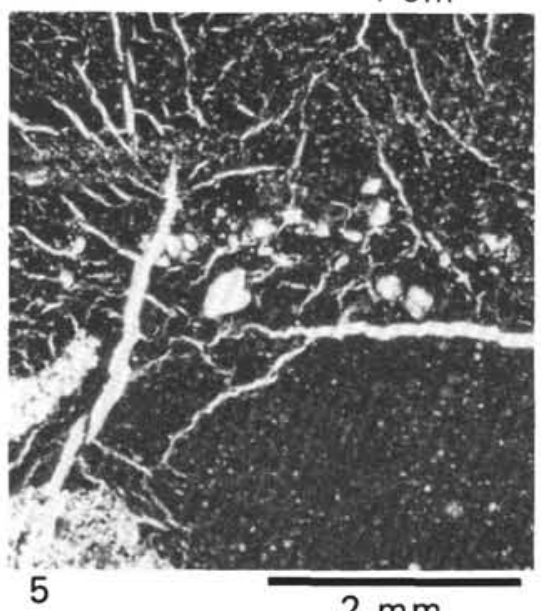

$2 \mathrm{~mm}$

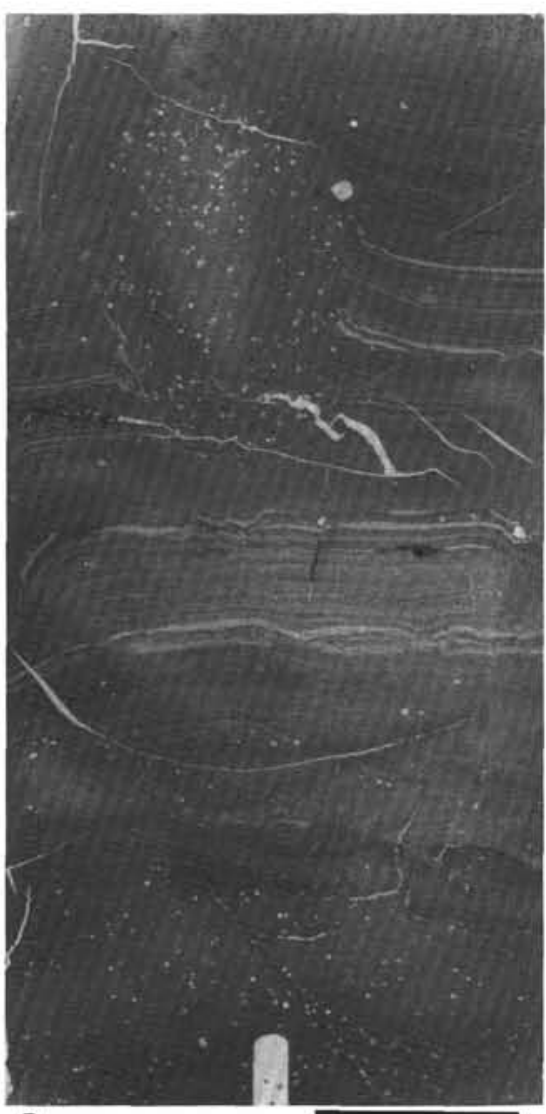

3

$1 \mathrm{~cm}$

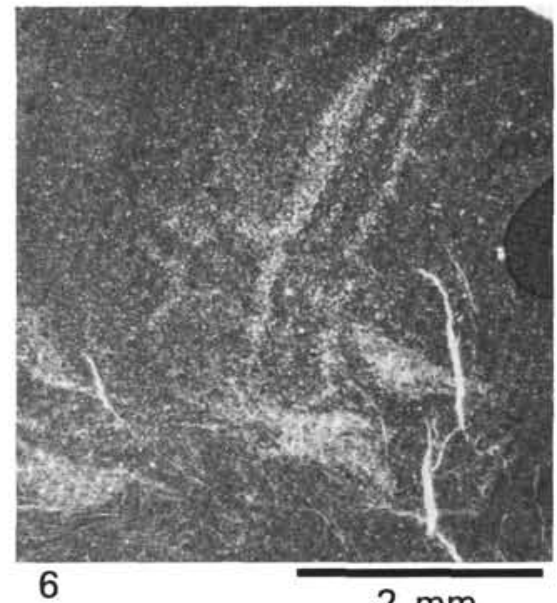

$2 \mathrm{~mm}$

Plate 3. Photographs of thin sections from Site 646 (see description in the text). 1. Sample 105-646B-6R-2, 84-91 cm; clayey mud with ice-rafted detritus. 2, 5. Sample 105-646B-9R-4, 57-64 cm, detrital carbonate turbidite; detail of the base of the turbidite. 3. Sample 105-646A-3R-4, 9-14 $\mathrm{cm}$; detrital carbonate turbidite; note the burrow at the upper part. 4. Sample 105-646B-37R-6, 144-150 cm; homogeneous bioturbated clayey silt, concentration of nannofossils in the burrows. 6. Sample 105-646B-11-2, 30-37 cm, bioturbated upper part of a detrital carbonate turbidite. 

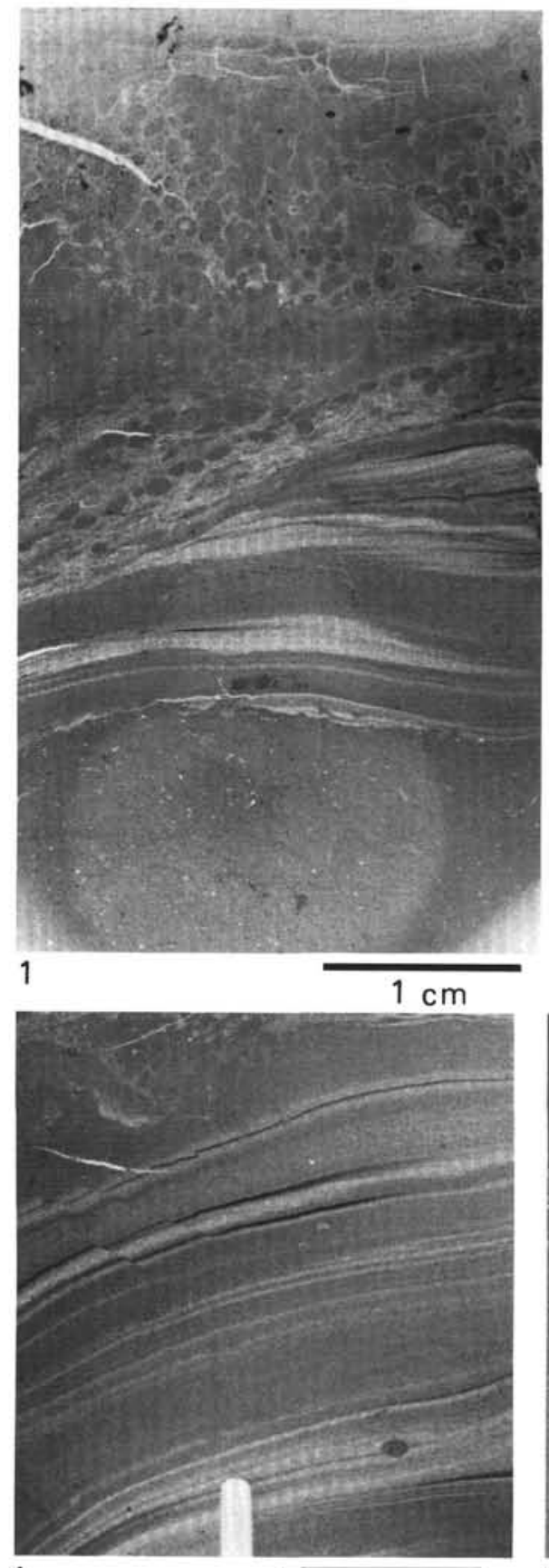

4

$1 \mathrm{~cm}$

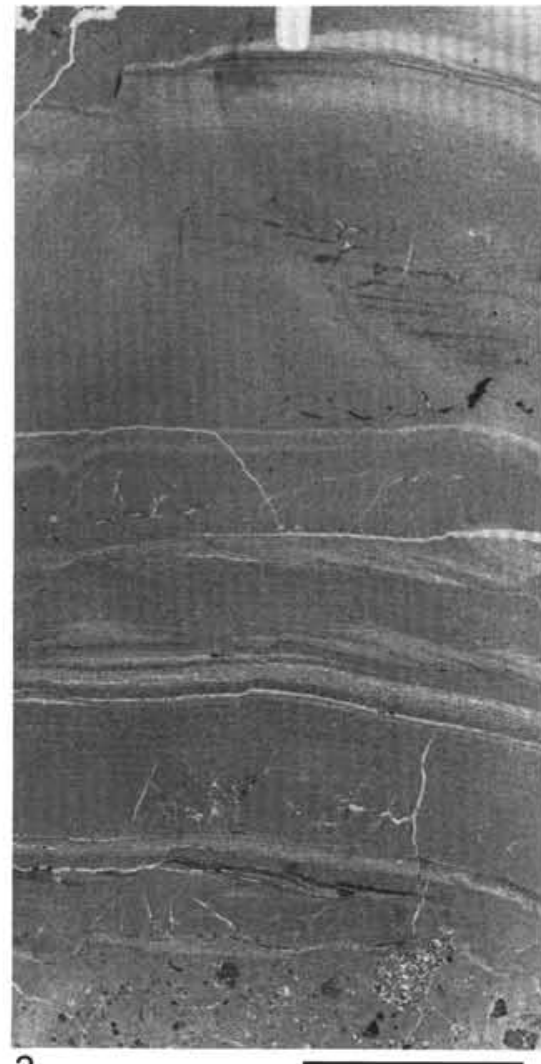

2

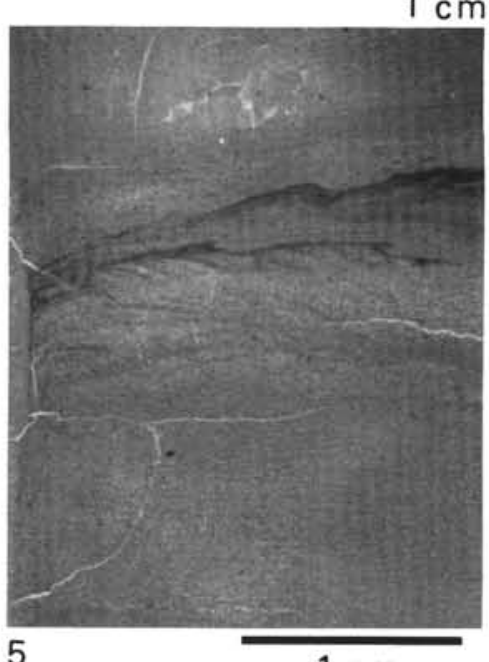

$1 \mathrm{~cm}$

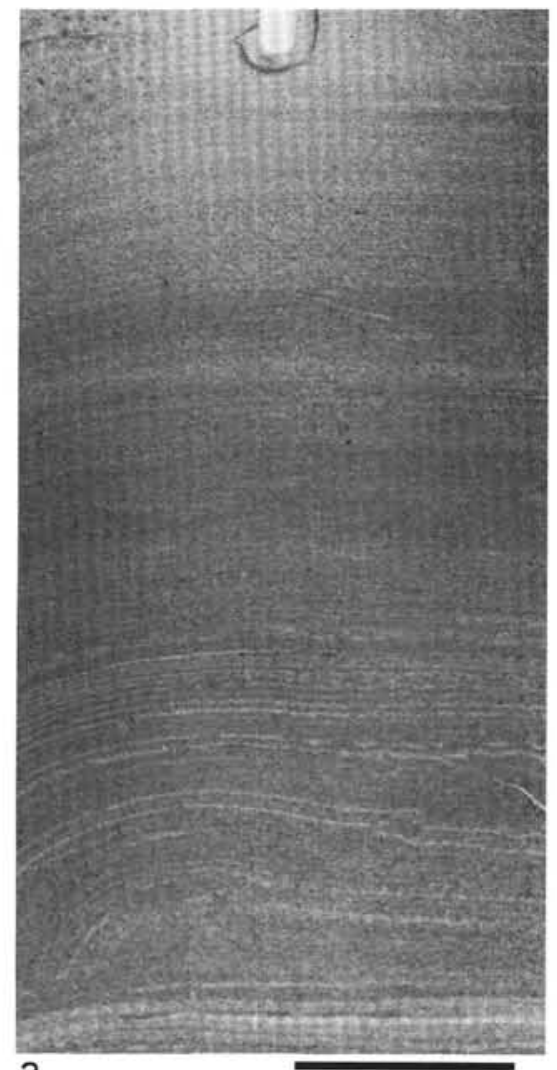

3

$1 \mathrm{~cm}$

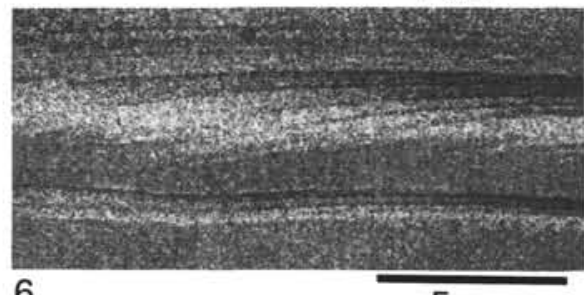

$5 \mathrm{~mm}$

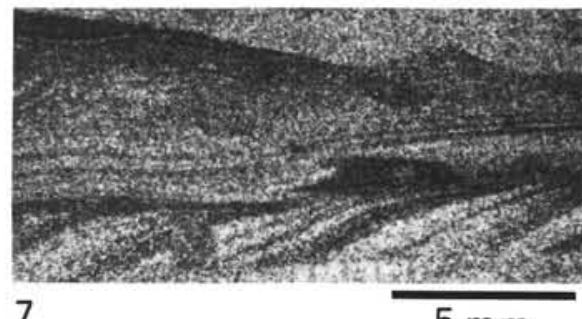

$5 \mathrm{~mm}$

Plate 4. Photographs of thin sections from Site 645 showing siliceous laminated silt beds (see description in the text). 1. Sample 105-646A-4H-4, $71-77 \mathrm{~cm}$; single silt bed with micropellets on top. 2. Sample 105-646B-10H-4, 71-77 cm; interlayered clayey silt and silt beds overlying ice-rafted detritus. 3. Sample 105-646A-11H-1, 103-109 cm; silt bed showing an apparent grading and a sequence of structure. 4, 6. Sample 105-646A-6H-5, $56-62 \mathrm{~cm}$; thinly parallel and cross-laminated silt bed. 5, 7. Sample 105-646A-10H-2, 63-68 cm; silt bed with transitional lower contact and concentration of heavy mineral on top of microripples at its upper part. 